Western University

Scholarship@Western

Aboriginal Policy Research Consortium International (APRCi)

3-2011

\title{
Imaginary subjects: school science, indigenous students, and knowledge-power relations
}

Joanna Kidman

Eleanor Abrams

Hiria McRae

Follow this and additional works at: https://ir.lib.uwo.ca/aprci

Part of the Educational Sociology Commons

Citation of this paper:

Kidman, Joanna; Abrams, Eleanor; and McRae, Hiria, "Imaginary subjects: school science, indigenous students, and knowledge-power relations" (2011). Aboriginal Policy Research Consortium International (APRCi). 188.

https://ir.lib.uwo.ca/aprci/188 
This article was downloaded by: [University of Western Ontario]

On: 18 November 2012, At: 07:40

Publisher: Routledge

Informa Ltd Registered in England and Wales Registered Number: 1072954 Registered

office: Mortimer House, 37-41 Mortimer Street, London W1T 3J H, UK

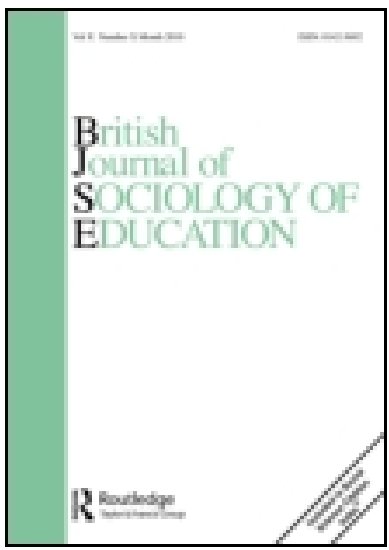

\title{
British J ournal of Sociology of Education
}

Publication details, including instructions for authors and subscription information:

http:// www.tandfonline.com/loi/ cbse20

\section{Imaginary subjects: school science, indigenous students, and knowledge-power relations}

\author{
J oanna Kidman ${ }^{a}$, Eleanor Abrams ${ }^{b} \&$ Hiria McRae ${ }^{c}$ \\ a He Parekereke, Faculty of Education, Karori Campus, Victoria \\ University of Wellington, PO Box 17-310, Wellington, New Zealand \\ ${ }^{b}$ Department of Education, University of New Hampshire, \\ Durham, New Hampshire, USA \\ ' Te Kura Maori, Victoria University of Wellington, New Zealand \\ Version of record first published: 09 Mar 2011.
}

To cite this article: J oanna Kidman, Eleanor Abrams \& Hiria McRae (2011): Imaginary subjects: school science, indigenous students, and knowledge-power relations, British J ournal of Sociology of Education, 32:2, 203-220

To link to this article: http:// dx.doi.org/ 10.1080/ 01425692.2011.547306

\section{PLEASE SCROLL DOWN FOR ARTICLE}

Full terms and conditions of use: http://www.tandfonline.com/page/terms-andconditions

This article may be used for research, teaching, and private study purposes. Any substantial or systematic reproduction, redistribution, reselling, loan, sub-licensing, systematic supply, or distribution in any form to anyone is expressly forbidden.

The publisher does not give any warranty express or implied or make any representation that the contents will be complete or accurate or up to date. The accuracy of any instructions, formulae, and drug doses should be independently verified with primary sources. The publisher shall not be liable for any loss, actions, claims, proceedings, demand, or costs or damages whatsoever or howsoever caused arising directly or indirectly in connection with or arising out of the use of this material. 


\title{
Imaginary subjects: school science, indigenous students, and knowledge-power relations
}

\author{
Joanna Kidman $^{\mathrm{a} *}$, Eleanor Abrams ${ }^{\mathrm{b}}$ and Hiria McRae \\ ${ }^{a}$ He Parekereke, Faculty of Education, Karori Campus, Victoria University of \\ Wellington, PO Box 17-310, Wellington, New Zealand; ${ }^{b}$ Department of Education, \\ University of New Hampshire, Durham, New Hampshire, USA; ${ }^{c}$ Te Kura Maori, \\ Victoria University of Wellington, New Zealand
}

(Received 19 April 2010; final version received 1 October 2010)

\begin{abstract}
The perspectives of indigenous science learners in developed nations offer an important but frequently overlooked dimension to debates about the nature of science, the science curriculum, and calls from educators to make school science more culturally responsive or 'relevant' to students from indigenous or minority groups. In this paper the findings of a study conducted with indigenous Maori children between the ages of 10 and 12 years are discussed. The purpose of the study was to examine the ways that indigenous children in an urban school environment in New Zealand position themselves in relation to school science. Drawing on the work of Basil Bernstein, we argue that although the interplay between emergent cultural identity narratives and the formation of 'science selves' is not as yet fully understood, it carries the potential to open a rich seam of learning for indigenous children.
\end{abstract}

Keywords: science education; Maori; indigenous; Basil Bernstein

\section{Introduction}

Much has been written in recent years about the disconnection between the field of scientific knowledge and school science. The impact of this disconnection is witnessed in OECD reports showing that, in developed nations such as Australia and New Zealand, an increasing number of students disengage with school science at around Year Eight (Bolstad and Hipkins 2008, 3; Tytler et al. 2008, 59). At the same time, fewer New Zealand students ascribe general value to science than many of their counterparts in the OECD (Caygill 2008, 28). This trend is particularly evident in the views expressed by indigenous Maori students who are less likely than majority culture students to see advances in science as being useful and are also less likely to express an interest in pursuing scientific studies or careers (Caygill 2008, 32). Moreover,

\footnotetext{
*Corresponding author. Email: Joanna.Kidman@vuw.ac.nz 
Maori children achieve at lower rates than non-Maori children in science both in schools where the Maori language is the medium of instruction and in English-medium schools (Stewart 2007, 30).

Common responses to the disengagement of working-class, indigenous, or minority group students at school have been calls by educators to make microlevel pedagogical practices more culturally responsive or more immediately relevant to the everyday experiences of those groups of students. However, definitions of what counts as relevant tend to be made on behalf of students rather than by them (McKinley 2001; 2005a, 230-231). Thus, in some cases, the result has been the introduction of tokenistic activities designed to 'celebrate' ethnic diversity (national costume days or ethnic food fairs, for example), whilst in other cases complex knowledge-power relations have been reduced to a primary focus on the cultural interactions between the teacher and the taught. The emphasis on the framing of these cultural interactions at the micro-level of classroom relationships has deservedly been the subject of much attention in teacher education, but it often comes at the expense of a close analysis of the classification of knowledge within the curriculum itself. It does not explain what is happening, for example, when indigenous students show early signs of disengagement with school science in high-performing schools where indigeneity is not only the norm but also drives the philosophy, language of instruction, and pedagogical character of the school. In this respect, the focus needs to shift from the cultural interactions of teachers and students as a problem to be solved through the introduction of culturally responsive or 'more relevant' teaching approaches to an exploration of the macro-level structuring of knowledge-power relations that surround indigenous schooling communities.

In this paper, we examine how Maori children in Maori-medium schooling contexts position themselves in relation to school science and ask what this tells us about knowledge-power relations within the science education domain. In doing so, we have drawn on the work of Basil Bernstein to argue that the structuring of science knowledge-power relations within the official recontextualising field creates tensions at the micro level of the classroom where pedagogical interactions are framed. Consequently, the positive value placed on indigenous culture within Maori-medium school settings, the dedication and commitment of indigenous teachers to the empowerment of their students, and the students' development of strong indigenous identities on the one hand, does not, on the other hand, fully compensate for unequal knowledge-power relations beyond the immediate world of the classroom that create a context of failure for Maori children in school science. We argue, however, that the potential to subvert dominant knowledge-power relations within the science curriculum can be harnessed by teachers, principals and local Maori communities; firstly, through a process of 'unmasking' and politicising existing knowledge-power relations within the science curriculum; and secondly, by reframing official science knowledge-power relations at the meso level of 
the school and the local indigenous community. In this paper we draw on data that are part of a transnational, multi-ethnic study of indigenous children's perceptions of middle school science. The project aims to identify the ways in which children from diverse indigenous communities position themselves as learners in relation to science curricula. Currently, the study involves Seediq/ Atayal participants in the mountain regions of Taiwan (Abrams et al. 2009), Mopan Mayan children in rural Belize, and Maori children in urban Maorimedium school settings in New Zealand. For the purposes of this paper, we are primarily focusing on data from New Zealand to elaborate a particular set of knowledge-power relationships within the science domain.

\section{Theoretical framework}

The means by which knowledge is constructed, circulated, regulated, evaluated, and reproduced are central to Bernstein's theory of power relations within the educational domain. These ideas are brought together under the rubric of the concept of the pedagogical device, which Bernstein describes as a system of rules that govern the way different kinds of knowledge are pedagogised and relayed to learners (Bernstein 1990, 1996, 2000). The process of pedagogising knowledge begins when knowledge is selectively drawn from the field in which it is produced (the field of production) and recontextualised for the purpose of pedagogical transmission and assessment. Thus, in relation to science education, aspects of the knowledge that is produced by working scientists and related knowledge workers, as well as the philosophical and technical debates and discourses that shape the various fields of science, are refashioned and recontextualised for consumption in schools. Bernstein identifies two primary locations in which these recontextualising processes take place:

We can distinguish between an official recontextualising field (ORF) created and dominated by the state and its selected agents and ministries, and a pedagogic recontextualising field (PRF). The latter consists of pedagogues in schools and colleges, and departments of education, specialized journals, private research foundations. (Bernstein 1996, 33)

The recontextualising process separates the richness and complexity of scientific knowledge from the contexts in which it is produced and condenses, homogenises, reconstructs, repackages, and redirects it towards a classroom audience. Recontextualised science knowledge is subsequently legitimated as a pedagogical product through a series of assessment practices devised by agents within the ORF, and to a lesser extent, the PRF, as a means of establishing control over its structure, content and regulation. The outcome of these recontextualising practices then, is a new construction of science oriented towards pedagogical goals that are often driven as much by ideological concerns as they are by educational priorities. This constitutes, as Bernstein suggests, an essentially imaginary discourse: 
As this discourse moves, it is ideologically transformed; it is not the same discourse any longer. I will suggest that as this discourse moves, it is transformed from an actual discourse, from an unmediated discourse to an imaginary discourse. As pedagogic discourse appropriates various discourses, unmediated discourses are transformed into mediated, virtual or imaginary discourses. From this point of view, pedagogic discourse selectively creates imaginary subjects. (Bernstein 2000, 33)

Moreover, the privileging of these imaginary subjects in the pedagogical domain within the mediating structure of the recontextualising field creates an epistemological separation between the field of knowledge production and science learners (Hipkins, Barker, and Bolstad 2005, 244). Within this model of knowledge relations, the pedagogical goal is not geared towards teaching students to become scientists in the field of knowledge production; rather, students are positioned as science learners who are ideally oriented towards the acquisition of school science and the existing knowledge-power relations that surround the subject.

The problem for indigenous students, including those in culturally supportive schooling environments in New Zealand, is that these recontextualising and assessment processes also increase the distance between the classroom and the field of indigenous science knowledge production. This happens when the official pedagogic discourse of science renders other constructions of knowledge, including indigenous scientific knowledge, invisible. It should be noted here that debates over the definitions of 'science', 'indigenous science' and indigenous knowledge production are highly contested in the domain of science education. Science is often viewed as a high-status concept in western education systems, and others have commented on the struggle for the 'ideological high ground' and whether indigenous knowledge should be included in the corpus of 'scientific knowledge' (Williams 1997, 20). For the purposes of this paper we have adopted the stance that Maori knowledge of the 'scientific' realm 'is a system which codifies knowledge according to its relatedness to environment and life issues rather than to what things are in themselves' (Williams 1997, 16). Thus we incorporate Maori tribal, traditional and historical knowledge of the natural world into this analysis but note that the contemporary Maori science is increasingly enacted as a hybridised domain where customary knowledge and new forms of emerging knowledge in which credentialed scientists (both Maori and non-Maori) are working with Maori tribal communities to combine and create knowledge. To this end there is evidence of a critical engagement between western and Maori knowledge traditions (Middleton and McKinley 2010, 240) that can be seen in crosscultural scientific research partnerships on matters such as climate change (King, Skipper, and Tawhai 2008), conservation (Ramstad et al. 2009), and wildlife sustainability (Moller et al. 2009). However, these recent initiatives and collaborations in the field of knowledge production have not yet had an impact either in the ORF or the PRF. 
A related aspect of Bernstein's work that concerns us here is the way in which different forms of pedagogical discourse create models of 'ideal' student identities that are reified by systems of assessment. As Bourne argues, "[e]ach form of pedagogy constructs a particular form of "ideal" student, whether as attentive, rule following and obedient, or as risk-taking and problem solving, for example' $(2008,46)$. These 'ideal' students become a benchmark against which other categories of learners are subsequently measured. Through this process, those who do not fit the ideal are identified as 'slow learners', 'gifted and talented', having special needs and so on (Bourne 2008). We argue here that the construction of science learners involves a set of culturally loaded ideals embedded in the curriculum that are imperfectly masked by a series of assessment devices that work towards making the 'ideal' appear normal, inevitable and logical. We argue, however, that these attempts to suppress alternatives may also have the effect of creating cultural gaps within which change can be effected. How, then, does this situation play out in the New Zealand curriculum and how does it affect the way in which Maori students position themselves in relation to school science and 'ideal' science learners?

\section{The science education curriculum in Maori schooling contexts in New Zealand}

A comprehensive Maori language immersion schooling system exists in New Zealand that begins in the early childhood years and extends through to tertiary education. It is now possible for Maori to participate in these learning environments throughout their entire education, including study at doctoral level. Primary schooling within these contexts takes place in schools known as kura kaupapa Maori. These are state primary schools where the language of instruction is Maori and the educational philosophies, aims and goals are drawn from the Maori world and reflect the aspirations of Maori communities. The guiding principles of these schools are set out in a foundation document entitled Te Aho Matua o ngā Kura Kaupapa Māori (Ministry of Education 1989) and they apply to all kura kaupapa Maori. In 2009, 6015 children were enrolled in these schools (Ministry of Education 2009b). It should be noted here that it is possible to learn the Maori language in other state schooling contexts, particularly where bilingual or language immersion classrooms are available; however, these classrooms are not the focus of this study.

Over the years there have been many debates about the science curriculum offered to Maori learners and these have been considered in detail elsewhere (McKinley 1996; Stewart 2009; McKinley and Keegan 2008). Of particular importance has been the reluctance of the Ministry of Education to endorse a science curriculum that incorporates Maori knowledge in non-tokenistic ways. In 1992 a landmark decision was made to write national curriculum documents in the Maori language, but it quickly became apparent that Maori would have 
little autonomy in developing curriculum statements that reflected Maori aspirations and cultural priorities. The science curriculum was written after a brief consultation period of six months - not long enough for Maori communities to debate the complex philosophical issues involved - and subsequently much of the focus was the development of Maori technical terminology (McKinley 1996). Moreover, the developers of the Maori-language science documents were instructed to retain the achievement outcomes of the English-language version of the science curriculum (McKinley and Keegan 2008, 139). Within the English-medium science curriculum, however, western modern science models were privileged over indigenous knowledge and as such a form of scientism was endorsed in ways that excluded alternatives and marginalised attempts to introduce other discourses (Wood and Lewthwaite 2008,3). This bias was therefore transported into the Maori-medium science curriculum documents. Thus, while kura kaupapa Maori teachers were expected to teach science in the Maori language, indigenous knowledge was not incorporated into the curriculum in meaningful ways nor were there spaces where the systematic introduction of indigenous knowledge discourses was possible (Stewart 2007, 59-61). Moreover, given that the achievement outcomes were grounded in discourses reconstructed from paradigms in western modern science, the 'ideal' learner was also oriented towards those models and achievement goals. Thus, the structuring of the science curriculum itself created a paradigm of success that positioned indigenous fields of knowledge production and learners with an orientation towards or curiosity about these epistemological alternatives, at the outer periphery. In this respect, indigenous science knowledge and western modern science paradigms were placed in direct opposition with each other as a result of the recontextualising process. This state of affairs has generated considerable debate and dissatisfaction amongst Maori schooling communities in recent years.

In an attempt to resolve some of these issues and as a response to a curriculum stock-take exercise conducted between 2000 and 2002, a partner document to the New Zealand Curriculum, Te Marautanga o Aotearoa, was developed for use in Maori-medium schools in 2008. The Ministry of Education has stated that this partner curriculum is not a simple translation of the existing curriculum into the Maori language, and attempts have been made to incorporate indigenous knowledge to a greater extent. However, western modern science models and achievement goals continue to dominate this curriculum particularly at advanced levels in the area of technology. Of note here is the role of kura kaupapa Maori teachers in developing Maori-medium science curriculum materials within their own local settings. As the Ministry of Education documents make clear, '[t]here is flexibility within Te Marautanga o Aotearoa for individual kura and teachers to implement, interpret, and utilise their own and/or local knowledge in learning contexts' (Ministry of Education 2007, 6). In other words, teachers have the freedom to develop a science curriculum and create assessment tools at the local level. In this 
respect part of the work of knowledge recontextualisation is shifted from the ORF to the PRF, although the achievement standards that students are expected to attain and national testing at the upper levels of secondary school continues to be regulated by the ORF.

Given the apparent open-endedness of the primary school curriculum structure, hegemonic discourses surrounding the knowledge-power relationship between the field of production and the ORF can be challenged and, indeed, some schools have been quick to recognise these possibilities. However, within Maori-medium classrooms, there are significant logistical constraints on teachers who wish to create meaningful change in science education at a local level and these need to be taken into account here. Firstly, there is a lack of qualified Maori-medium science teachers, or teachers with a strong science background, available to teach in kura kaupapa Maori. This has significant implications for Maori-medium schools because, as Morais, Neves, and Pires $(2004,84)$ have found, teachers' scientific competence and familiarity with investigative competencies have a profound effect on children's development of complex cognitive competencies in the science classroom. In addition, scientific terminology is still being developed for Maori-medium classrooms (Stewart 2009). Secondly, the quality and availability of print and electronic resources for use in kura kaupapa Maori science classes is uneven (McKinley and Keegan 2008, 138; Gilbert, Hipkins, and Cooper 2005, 6; Waiti and Hipkins 2002, 4). Thirdly, there is no agreed criteria about what constitutes a scientifically literate person able to operate in both Maori and non-Maori worlds and the complex epistemological issues related to this question have not been adequately addressed, either within the centrally managed ORF or the more disjointed and diffuse fields of the PRF.

By vesting primary responsibility for the development of local curricular materials and assessment tools in the PRF without addressing the lack of teaching materials and staffing resources within Maori-medium science education, and also by disengaging with critical philosophical debates about indigenous scientific literacy in Maori-medium classrooms, the state is able to proclaim the autonomy of Maori schooling at the same time as actively undermining it. We are in agreement with McKinley $(1996,157)$, who contends that in the early days of Maori-medium science curriculum development these apparently open-ended processes allowed the state to abdicate responsibility for Maori failure by passing it on to schooling communities, at the same time as claiming the kudos for appearing to support a social justice agenda. We further argue that this continues to be the case with the revised Maori-medium curriculum particularly in the domain of science and technology. How, then, do Maori children position themselves in relation to the science curriculum in a schooling environment where a high priority is accorded to the development of indigenous cultural identities, and why, if cultural responsiveness in relation to indigenous identity construction is embedded in the pedagogical and 
philosophical mission of a school, are some Maori children showing early signs of disengagement with school science?

\section{Constructing 'Others' in science}

In a case study of 32 Maori children (aged 10-12 years) enrolled at a Maori language immersion school in New Zealand, we identified a series of epistemological and structural boundaries and distances that frame the pedagogical climate of the science classroom. Despite being located within a schooling context where a high value is accorded to the construction and maintenance of cultural identities, the students positioned themselves in the role of 'Other' in relation to the domain of scientific knowledge production, and most also indicated a degree of disconnection with school science. The students were interviewed in groups of three to six people by two Maori researchers, one of whom is a fluent speaker of the Maori language. Interviews were conducted in English, although at times during the course of the interviews some students chose to respond either in Maori or in a mixture of Maori and English. The cohort size is small and localised within one school, and for this reason the results are speculative and should be treated with caution. However, a strong correlation was found between the findings of this study and recent OECD and Ministry of Education research about the attitudes of students towards school science (Caygill 2008; OECD 2007; Crooks, Smith, and Flockton 2008), and this suggests that a level of comparability was achieved.

\section{The schooling context}

The school is a kura kaupapa Maori located in a city in the North Island of New Zealand. It has what is known in New Zealand, as a decile 3 ranking from the Ministry of Education. This ranking denotes that the socio-economic status of the school community is in the lower $30 \%$ of the New Zealand population. The school has consistently received exceptionally positive Educational Review Office reports over the years. ${ }^{1}$ Recent Educational Review Office reports make particular mention of the strong leadership shown by the Principal and the extensive professional culture of teachers within the school. The students have attained high levels of fluency in the Maori language and, in addition, the majority has achieved literacy and numeracy levels at, or above, the national average for their age group. These aspects of school life are also immediately evident to visitors to the school. The Principal is in constant faceto-face contact with the students' family members; the children are articulate, friendly and openly express their respect and affection for other members of the school community, including teachers, and family members are made welcome when they visit the school. The philosophical mission of the school is well grounded in Maori perspectives about childhood and education as documented in Te Aho Matua o nga Kura Kaupapa Maori - the underpinning 
philosophy of kura kaupapa Maori schooling. In addition, the physical environment of the school is welcoming; the facilities are clean and well maintained and there are numerous examples of Maori artwork (much of which is created by the children themselves) on the walls around the school.

\section{Attitudes towards school science}

The National Education Monitoring Project, a Ministry of Education-funded longitudinal study of school achievement in New Zealand, has found that Year Four students in New Zealand schools are generally less confident that they learn a lot of science at school and an increasing number of students in that year group feel that they learn very little in science (Crooks, Smith, and Flockton 2008, 62). In addition, more students are reporting that they 'never' do really good things in science at school (Crooks, Smith, and Flockton 2008). Our study reflected similar findings. The majority of students in this school said that they 'don't do that much science' or that they 'never' do science. This response contrasted with the view of the teaching staff who told us that the students were engaged in a range of science-related activities but these were not directly identified as science. One participant recognised that this was the case, as is shown the following exchange:

Boy 1: We don't do science.

Boy 2: Yeah we do. We just don't know we're doing it.

Some of the participants had difficulty distinguishing between science and mathematics as separate curriculum domains. For example when asked what she had studied in science that year, one participant responded;

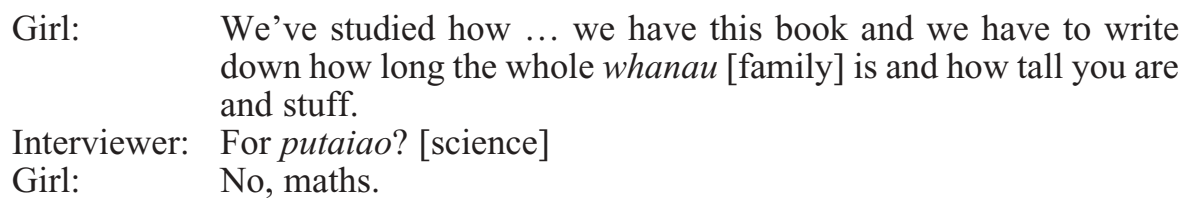
down how long the whole whanau [family] is and how tall you are and stuff.

Interviewer: For putaiao? [science]

Girl: $\quad$ No, maths.

These exchanges support the view that many primary school students may be uncertain about what counts as a science learning experience (Bolstad and Hipkins 2008, 5) and, in this respect, their responses need to be treated with caution as they may reflect the fact that science activities tend to be integrated into the broader curriculum in the middle school years rather than taught as a separate subject. Indeed, it is not uncommon for middle school science to be delivered in this way. Studies in American middle schools have found that science topics are frequently treated in a superficial manner rather than with an in-depth focus (Kesidou and Roseman 2002, 540), while in Europe traditional curricula in primary school science in some national systems are fragmented and lacking in overall coherence (Osborne and Dillon 2008, 8), although some countries have a more integrated curricula than others (2008, 
20). In terms of the recontextualisation of school science, however, the blurred knowledge boundaries between science and other school subjects in the middle school years may also be a reflection of the apparently 'hands-off approach' taken within the ORF towards science curriculum development, and subsequent confusion within the PRF about what is expected and what can reasonably be delivered.

Very few of the participants expressed an active dislike of science; indeed, just less than one-half of the students told the interviewers that they enjoyed the subject. However, an equal number of participants reported that they were unsure whether they enjoyed science or that they enjoyed it only sometimes. There is some evidence to suggest that attitudes towards school science may be formed before the age of 14 years, earlier than previously thought (Tytler et al. 2008, 86; Bolstad and Hipkins 2008, 11). If this is the case, then many of the participants in our study were already showing signs of disengagement. This may be due to a range of factors including confusion about what school science entails, a lack of clear subject boundaries in science during the middle school years when most other curriculum subjects are more readily identifiable, or a more general lack of value that tends to be accorded to science by young people in developed nations worldwide (Schreiner and Sjoberg 2007). However, it also reflects the problem that many Maori students do not readily 'see' themselves in science; indeed, only two participants had actively considered a career in the field of science knowledge production. One female participant expressed a desire to become a paleontologist, and the other, a male participant, wanted to be a marine biologist - but even so, they shared similar beliefs to their peers; namely that scientists are lonely white men in white coats.

\section{Scientists as lonely men in white coats}

Despite the fact that science is not often clearly defined as a discrete subject within the middle school curriculum, young people have clear ideas about scientists, what they do, and the kinds of lives they lead. These perceptions are a useful way of thinking about how indigenous learners construct the field of science in their imaginations and how they deploy these constructions as they position themselves in relation to science as both a field of knowledge production and as a curricular discourse.

During the interviews, the participants were asked to visualise and describe a scientist. For the most part, their ideas were drawn directly from popular culture, particularly what they had seen in films and on television. With regard to the latter, the participants frequently referenced the 'mad scientist' of cartoons and the proliferation on New Zealand television of American primetime forensic dramas such as CSI, Bones, or NCIS and crime dramas that included scientist characters. Their overall perception of scientists was of busy, work-focused, bespectacled, 'brainy' white men wearing white coats in 
laboratory settings. The following extracts are representative of the responses given when asked what scientists do:

They make Frankensteins and that. (Boy, age 11)

They make bombs. (Boy, age 10)

They make weapons. (Boy, age 11)

He discovers things to make things evil. (Girl, age 11)

They make potions and smoke. (Boy, age 10)

They test things. They tip things in the cup and they bubble. (Boy, age 10)

To a certain extent, our findings reflect those of other studies in so far as stereotyped images of scientists are concerned (for example, Turner and Ireson 2010); however, what differs from other investigations is the degree to which the notion of a normative discourse of 'whiteness' is applied by Maori children to their understandings of science workers. In her work on the representation and construction of Maori women scientists' identities in scientific discourse in New Zealand, McKinley (2005b) has argued that a pervasive, normative discourse of 'whiteness' renders Maori science identities invisible, and this is particularly true for Maori scientists who are female. We argue that these discourses have also influenced Maori children's understandings of scientists in subtle ways. However, despite the fact that all of the respondents viewed scientists in rather stereotyped ways, five participants also suggested a wider range of activities in which scientists might engage:

I know there are some scientists who help us to find new creatures. And some scientists help to stop global warming. (Girl, age 12)

They find out what's causing stuff like global warming. (Girl, age 10)

They find things out. Like astronomy. Like what's on Jupiter. What Saturn's rings are made out of. (Boy, age 12)

Some scientists know how the world is made ... (Boy, age 12)

... Yeah, like thermal waters. Like at Turangi and Rotorua. Show what they do and how they're made. (Boy, age 12)

Social, tribal and family networks are important elements of Maori cultural and tribal identity, and a great deal of time is spent in developing and maintaining an extensive system of interactions within the collective. For that reason we were interested to find out whether the students attributed similar values to scientists. However, when asked whether they thought that scientists might have families or friends, most of the participants described scientists as having limited or non-existent social and familial networks, as the following extracts suggest:

Well I watch movies and there's scientists in them but most of them don't really have families. They're lonely. (Girl) 
Well, really to my imagination, a scientist can have a small family but a scientist always has to be on the job. Stay right where he is. In the lab. (Girl)

They might not have a family of their own because they might be too busy and they haven't got a social life. (Girl)

They might have a wife who has the same job. (Girl)

If my Dad was a scientist, I just wouldn't see him. Like he wouldn't spend any time with me ... 'Cos they're always working and stuff. (Boy)

Boy 1: $\quad$ Some scientists just worry about their projects, not their family...

Boy 2: $\quad$... They worry they might not finish their work in time...

Boy 3: $\quad$... They'll worry if they might not get promoted.

Boy 4: [They might have friends] from the office ...

Boy 5: $\quad$... From the laboratory.

Interviewer: So they might not have many other friends?

Boy 5: $\quad$ Some might not.

Boy 4: $\quad$ Some might not understand them.

Interviewer: They're misunderstood?

Boy 5: $\quad$ Yeah, 'cos they're on different pages.

Case studies with indigenous Seediq/Atayal children in Taiwan conducted as part of this study show that they hold similar attitudes to Maori children towards science workers in the field of knowledge production. Preliminary findings suggest that they also typify scientists as socially and culturally disconnected white men who enact a particular form of morality in their laboratories. Interestingly, the Seediq/Atayal participants, who also have access to television and film representations of scientists drawn from American primetime dramas, depicted scientists not as dominant culture Chinese as might be expected, but as white men. On the other hand, the Mopan participants in Belize have limited access to television and film and also have greater exposure to working scientists. Scientific field research teams regularly visit their village to conduct studies on wildlife, the natural environment, and agricultural practices. Our preliminary findings show that Mopan children are more likely to portray science workers as Mayan rather than as white men. Thus indigenous children in the industrialised nations of New Zealand and Taiwan appear more likely to draw their understandings of science and science workers from gendered, cultural, ethical and ethnic constructs that do not actively include indigenous frames of reference. If these constructs become the benchmark against which Maori children measure themselves, it is not surprising that many respondents in our study have begun to position themselves outside the science domain.

Moreover, these findings suggest that the epistemological distance created within the ORF between indigenous children in industrialised nations and the western modern science field of knowledge production as well as the indigenous field of knowledge production opens gaps, establishes apparently 
impermeable boundaries, and closes off epistemological alternatives for indigenous learners. Mopan children, who have greater exposure to working scientists who are regularly hosted in their village, and less exposure to the normative values of western popular culture representations of science and scientists, are more open to visualising scientists as indigenous people. This does not mean they are all engaged with science or aim to become scientists; rather, it suggests that they perceive more permeable boundaries between themselves and the field of production. It is clear that many Maori students in culturally affirming schooling environments do not feel a sense of belonging within the science domain; however, each of the participants expressed a strong sense of identification as members of a community of Maori-language speakers, and we argue that these affiliations have the potential to reframe science knowledge relationships.

\section{Belonging, language and identity}

In contrast to the ambivalent or negative feelings about science expressed by several participants, all of them, without exception, ascribed value to being Maori and being able to speak the Maori language. In this respect, they drew their sense of cultural identity from their membership of a Maori-language community. A selection of responses that highlight these attitudes is as follows:

Interviewer: Why is it important to you to speak Maori?

Boy: $\quad$ So you don't lose it.

Girl: $\quad$ So, ki te whangai ki te tamariki [you can share it with your children].

Girl: $\quad$ So you can carry it on across generations.

Interviewer: Why is it important to carry it on?

Boy: 'Cos it's our language.

It was given to us by our tupuna [ancestors]. (Boy)

Do you know the African Americans can speak English but if the other Africans spoke to them they can't speak their own language back. So they just speak English. And sometimes the English speaking is, like, taking over our language. (Girl)

People have really different tikanga [cultural protocols]. Like, English people have different tikanga than Maori people. So really, it's important to know about your culture because then you'll know more about who you are. (Girl)

Given these attitudes about the significance of the Maori language in indigenous identity construction, what cultural devices, then, might indigenous children and teachers in industrialised nations deploy to reposition themselves in relation to both school science and the fields of scientific knowledge production? 


\section{Discussion}

In the past, it has been assumed that the use of indigenous languages in the classroom will provide a meaningful and culturally relevant vehicle for learners to express a particular world-view. Indeed, it has become something of a truism that language and cultural identity are mutually constitutive (Tsui and Tollefson 2007, 2; Benton 2007, 173). This approach has been taken in New Zealand with regard to the Maori Language Education Policy. Ministry of Education documents include the following statement:

Language is the essence of culture. Te reo Maori [the Maori language] is the vehicle through which Maori culture, spirituality and thoughts are expressed. As one of the official languages of New Zealand, te reo Maori supports the development and celebration of our national identity, enhances the mana whenua [Maori tribal customary authority over defined areas] of our indigenous people and contributes to a creative and successful economy. (Ministry of Education 2009a, 26).

Thus, in addition to Ministry attempts to make learning more "culturally relevant' for Maori learners through the recognition and use in classrooms of the Maori language, the Maori language is also expected to contribute to national identity, Maori customary authority and the economy. We suggest that these are very high expectations indeed. However, saying something in an indigenous language does not automatically mean that an indigenous world-view is being drawn upon, nor does it necessarily reflect indigenous knowledge or even something that is culturally relevant to the speaker. In order for those connections to be made, indigenous learners also need to be able to access the contexts that surround the language; they need to be connected with the cultural memories, histories and richness of cultural places and spaces. We argue that in relation to science education, Maori learners - even those in kura kaupapa Maori where 'Maori-ness' is the norm - are cut adrift from both western modern science and indigenous Maori scientific knowledge through the recontextualising that takes place in the ORF. In this regard, the deployment of the Maori language as a feature of the pedagogical device and children's fluency in the Maori language are not enough to stem the tide of students who are disengaging with science nor reverse their perceptions of scientists as lonely white men in laboratories. This is because the Maori language per se does not automatically connect or transport Maori learners into the fields of production since they first must learn the imaginary discourse of school science - a discourse that is itself disconnected from the sources of knowledge production. Furthermore, the scientific terminology that is rapidly being developed to meet the needs of the Maori-medium science curriculum may also be viewed as an imaginary discourse. This is not to suggest that Maori language development should not happen, we believe this is important work but the terminology is not evolving in response to Maori scientific priorities or at a pace that is determined by Maori so much as it is being invented because 
the state has deemed it necessary to enhance curriculum development in science education.

If Maori-medium pedagogical transmission is not, on its own, enough to draw indigenous students into the domain of science on their own terms, Bernstein's work may offer a way forward. The recontextualising of knowledge, he argues, creates disconnections between learners and teachers. It creates apparently impermeable boundaries around which knowledge-power relations take shape. Bernstein calls these spaces between different worlds of knowledge a 'potential discursive gap' and he contends that these gaps, paradoxically, create the conditions for producing different relations between these worlds (Bernstein 2000, 30). He argues:

I want to suggest that this gap or space can become (not always) a site for alternative possibilities, for alternative realisations of the relation between the material and the immaterial ... This potential gap or space I will suggest is the site for the unthinkable, the site of the impossible, and this site can clearly be both beneficial and dangerous at the same time. This gap is the meeting point of order and disorder, of coherence and incoherence. It us the crucial site of the yet to be thought. (Bernstein 2000, 30; emphasis in original)

We argue that the potential to subvert dominant knowledge-power relations within the science curriculum exists and can be harnessed by teachers, principals and local indigenous communities through a process of 'unmasking' and politicising existing knowledge-power relations within the science curriculum and by reframing official science knowledge-power relations at the meso level of the school and the local community. However in indigenous contexts, this requires a shift in the framing of school science. Maori language revitalisation has been an important concern for educators in New Zealand and it is an area in which kura kaupapa Maori schools are performing well. The Maori language opens up spaces where identity development can take place, but science education is not yet fully aligned with the cultural contexts that could potentially be created within Maori-medium classrooms. In this respect it may timely to shift the gaze from cultural relevance - kura kaupapa Maori have already achieved that goal - to political relevance. The participants in this study have a strong commitment to Maori identity development and even in their middle school years they have begun to politicise these identities within New Zealand's colonial historical context. But there are gaps between those understandings and the way that they might be linked to the politics of science and Maori aspirations. In other words, a Maori way of viewing science and the wider knowledge-power relationships that surround school science is a site where the yet-to-be-thought connections are yet to be made. The gap is there, but its potential is under-utilised.

In the middle school years, the science education curriculum is less prescriptive and content-driven than in the later stages of schooling, and it is here that Maori political perspectives on science can be debated. It is also 
within this environment that knowledge-power relationships and epistemological distances can be exposed, critiqued, and related to the lived social and political contexts of Maori learners and their communities. Even at the level of exposing perceptions of scientists as 'lonely men in labs' and thinking about what a Maori scientist or a scientifically literate Maori might look like and what he or she might do to assist (or hinder) Maori aspirations, is a way of opening up spaces for teachers and learners to reflect on knowledge-power relations within the domains of science and science education. The work of revealing those relationships, the taken-for-granted boundaries, the masking of the recontextualising process through various assessment protocols, and the construction of imaginary subjects within the ORF, and understanding how and why epistemological distances and 'ideal' science learners are created, begins in the PRF; with teacher educators, schools and Maori communities. We suggest that although the interplay between emergent cultural identity narratives and the formation of 'science selves' is not as yet fully understood, it carries the potential to open a rich seam of learning for indigenous children.

\section{Acknowledgements}

The authors would like to acknowledge the support of Fulbright New Zealand for a senior scholarship that enabled one of the authors to contribute to this research. They also wish to thank Nga Pae o te Maramatanga, the Maori Centre for Research Excellence, University of Auckland, for ongoing support of this study.

\section{Note}

1. The Educational Review Office is a government department with the task of evaluating and publicly reporting on the performance of every school in New Zealand on a three-year cycle, on average.

\section{References}

Abrams, E., C-F. Yen, E. Blatt, and L. Ho. 2009. Unpacking the complex influence of schooling, sense of place and culture on the motivation of Taiwanese elementary school students to learn science in school: Using a socio-cultural approach with phenomenological research methodologies. In Diversity in environmental educational research, ed. D. Zandvliet, 103-30. Rotterdam: Sense Publishers.

Benton, R.A. 2007. Mauri or Mirage? The status of the Maori language in Aotearoa New Zealand in the third millennium. In Language policy, culture, and identity in Asian contexts, ed. A.B.M. Tsui and J.W. Tollefson. Mahwah, NJ: Lawrence Erlbaum Associates.

Bernstein, B. 1990. The structuring of pedagogic discourse. London: Routledge.

Bernstein, B. 1996. Pedagogy, symbolic control, and identity: Theory, research and critique. London: Taylor \& Francis.

Bernstein, B. 2000. Pedagogy, symbolic control, and identity: Theory, research and critique. Rev. ed. Lanham, MD: Rowman \& Littlefield Publishers. 
Bolstad, R., and R. Hipkins. 2008. Seeing yourself in science: The importance of the middle school years. Report prepared for the Royal Society of New Zealand. Wellington: New Zealand Council for Educational Research.

Bourne, J. 2008. Official pedagogic discourses and the construction of learners' identities. In Encyclopedia of language and education. Vol. 3: Discourse and education, ed. M. Martin-Jones, A.M. de Mejia, and N.H. Hornberger, 41-52. 2nd ed. New York: Springer.

Caygill, R. 2008. PISA 2006: Student attitudes to and engagement with science: How ready are our 15-year-olds for tomorrow's world? Wellington, New Zealand: Ministry of Education.

Crooks, T., J. Smith, and L. Flockton. 2008. Science assessment results 2007. Dunedin, New Zealand: The Educational Assessment Research Unit, University of Otago.

Gilbert, J., R. Hipkins, and G. Cooper. 2005. Fact or fiction: Using narrative pedagogy in school science education. Paper presented at the Redesigning Pedagogy: Research, Policy, Practice Conference, 30 May-1 June, in Nanyang University Institute of Education, Singapore.

Hipkins, R., M. Barker, and R. Bolstad. 2005. Teaching the 'nature of science': Modest adaptations or radical reconceptions? International Journal of Science Education 27, no. 2: 243-54.

Kesidou, S., and J.E. Roseman. 2002. How well do middle school science programs measure up? Findings from Project 2061's curriculum review. Journal of Research in Science Teaching 39, no. 6: 522-49.

King, D.N.T., A. Skipper, and W.B. Tawhai. 2008. Maori environmental knowledge of local weather and climate change in Aotearoa-New Zealand. Climatic Change 90, no. 4: 385-409.

McKinley, E. 1996. Towards an indigenous science curriculum. Research in Science Education 26, no. 2: 155-67.

McKinley, E. 2001. Cultural diversity: Masking power with innocence. Science Education 85, no. 1: 74-6.

McKinley, E. 2005a. Locating the global: Culture, language and science education for indigenous students. International Journal of Science Education 27, no. 2: 227-41.

McKinley, E. 2005b. Brown bodies, white coats: Postcolonialism, Maori women and science. Discourse: Studies in the Cultural Politics of Education 26, no. 4: 481-96.

McKinley, E., and P.J. Keegan. 2008. Curriculum and language in Aotearoa New Zealand: From science to putaiao. L1 - Educational Studies in Language and Literature 8, no. 1: 135-47.

Middleton, S., and E. McKinley. 2010. The gown and the korowai: Māori doctoral students and the spatial organisation of academic knowledge. Higher Education Research and Development 29, no. 3: 229-43.

Ministry of Education. 1989. Te Aho Matua: Tomorrow's schools Kura Kaupapa Māori Working Group. Wellington, New Zealand: Ministry of Education.

Ministry of Education. 2007. Translation of Te Marautanga o Aotearoa: He tauira hei korerorero. Wellington, New Zealand: Ministry of Education.

Ministry of Education. 2009a. Annual report for the year ended 20 June 2009. Wellington, New Zealand: Ministry of Education.

Ministry of Education. 2009b. Kaupapa Maori and Kura Teina. Education counts. Wellington, New Zealand: Ministry of Education.

Moller, H., P. O’Blyver, C. Bragg, J. Newman, R. Clucas, D. Fletcher, J. Kitson, S. McKechnie, D. Scott, and Rakiura Titi Islands Administering Body. 2009. Guidelines for cross-cultural participatory action research partnerships: A case study of 
a customary seabird harvest in New Zealand. New Zealand Journal of Zoology 36, no. 3: 211-41.

Morais, A., I. Neves, and D. Pires. 2004. The what and the how of teaching and learning: Going deeper into sociological analysis and intervention. In Reading Bernstein, researching Bernstein, ed. J. Muller, B. Davies, and A. Morais, 75-90. London: Routledge Falmer.

OECD. 2007. PISA 2006: Top of the class: High performers in science in PISA 2006. Paris: OECD.

Osborne, J., and J. Dillon. 2008. Science education in Europe: Critical reflections. Report to the Nuffield Foundation. London: The Nuffield Foundation, Kings, College, London.

Ramstad, K.M., G. Paine, D.L. Dunning, A.F. Geary, S.N. Keall, and N.J. Nelson. 2009. Effective partnerships between universities and indigenous communities: A case study in tuatara conservation in Aotearoa. Journal of the Royal Society of New Zealand 39, no. 4: 229-31.

Schreiner, C., and S. Sjoberg. 2007. Science education and young people's identity construction - two mutually incompatible projects? In The re-emergence of values in the science curriculum, ed. D. Corrigan, J. Dillon, and R. Gunstone, 231-48. Rotterdam: Sense Publishers.

Stewart, G.M. 2007. Kaupapa Maori Science. Unpublished EdD thesis, University of Waikato, Hamilton, New Zealand.

Stewart, G.M. 2009. Science in the Maori-medium curriculum: Assessment of policy outcomes in Putaiao education. Educational Philosophy and Theory [Early View]. DOI: 10.1111/j.1469-5812. 2009.00557.x.

Tsui, A.B.M., and J.W. Tollefson. 2007. Language policy and the construction of national cultural identity. In Language policy, culture, and identity in Asian contexts, ed. A.B.M. Tsui and J.W. Tollefson, 1-24. Mahwah, NJ: Lawrence Erlbaum Associates.

Turner, S., and G. Ireson. 2010. Fifteen pupils' positive approach to primary school science: When does it decline? Educational Studies 36, no. 2: 119-41.

Tytler, R., J.F. Osborne, G. William, K. Tytler, and J. Cripps Clark. 2008. Opening up pathways: Engagement in STEM across the primary-secondary school transition. A review of the literature concerning supports at primary-secondary transition. Canberra: Commissioned by the Australian Department of Education, Employment and Workplace Relations.

Waiti, P., and R. Hipkins. 2002. Cultural issues that challenge traditional science teaching. Paper presented at the Third Annual New Zealand Science Education Symposium, 22-23 November, in Massey University, Wellington, New Zealand.

Williams, D. 1997. Matauranga Maori and Taonga. The nature and extent of treaty rights held by Iwi and Hapu in indigenous flora and fauna cultural heritage objects and valued traditional knowledge. WAI 262. Report to the Waitangi Tribunal. Wellington, New Zealand: Waitangi Tribunal Publications.

Wood, A., and B. Lewthwaite. 2008. Maori science education in Aotearoa New Zealand. He putea whakarawe: Aspirations and realities. Cultural Studies of Science Education 3: 625-62. 